\title{
Capital Structure Decisions and Corporate Performance: Evidence from Chinese Listed Industrial Firms
}

\author{
Ratnam Vijayakumaran \\ Department of Financial Management, Faculty of Management Studies and Commerce \\ University of Jaffna, Sri Lanka \\ E-mail: rvijay@univ.jfn.ac.lk
}

Received: March 12, 2017 Accepted: October 22, 2017 Published: December 31, 2017

doi:10.5296/ijafr.v7i2.12455

URL: https://doi.org/10.5296/ijafr.v7i2.12455

\begin{abstract}
Market imperfections such as taxes, asymmetric information and agency problems make capital structure decisions relevant to the value of the firm. More specially, the agency theory suggests that debt financing is one of the governance mechanisms to mitigate agency costs of equity capital and thus to enhance firm performance. This paper provides new empirical evidence on the performance effects of capital structure decisions using a large panel of Chinese listed industrial firms. Using fixed effects regression method, the study finds that leverage is positively related to firm performance, suggesting that debt financing now acts as a governance mechanism for Chinese listed firms to enhance their performance.
\end{abstract}

Keywords: Capital structure decisions, Agency problem, Corporate governance, Bank financing, Corporate performance, China

JEL Classification: D22, G32; G34; G38; G39; L25

\section{Introduction}

Modigliani and Miller's (1958) irrelevant theory argues that capital structure is irrelevant to the value of the firm under perfect capital market conditions (i.e., free entry, absence of transaction costs and taxes and equal access to information). However, in real world, the existence of market frictions such taxes, asymmetric information and agency problems makes capital structure decisions relevant to the value of the firm (Modigliani \& Miller, 1963; Jensen \& Meckling, 1976; Myers, 1977; Myers \& Majluf, 1984) [See Harris and Raviv (1991) and Shleifer and Vishny (1997) for excellent surveys]. These theories suggest that firms 


\section{$\triangle$ Macrothink}

International Journal of Accounting and Financial Reporting

ISSN 2162-3082

2017, Vol. 7, No. 2

engage in active financing choices of various financial instruments such as debt and equity, resulting in cross-sectional variations in debt ratios, differing debt maturity structures across industries, and complex financial contractual arrangements which in turn may affect the value of firms differently (Barnea, Haugen \& Senbet, 1981).

More specially, Jensen and Meckling's agency theory (1976) argues that even in the absence of taxes, debt capital can have significant effects on corporate performance since it works as a governance mechanism for firms. Conflicts of interests between managers and shareholders arising from the separation of ownership and control in corporations create considerable agency costs for the firms and to the economy as a whole (Berle \& Means, 1932; Jensen \& Meckling, 1976). Several governance mechanisms have been devised to mitigate these agency conflicts in the firms. Agency theory suggests that one such mechanism is debt financing. Greater debt financing may provide mangers with the incentives to reduce agency costs through the threat of liquidation, which causes personal losses to managers in terms of salaries, reputation, perquisites, etc. (e.g., Grossman \& Hart, 1982; Williams, 1987), and through pressure to generate cash flow to pay interest expenses (Jensen, 1986). This agency perspective is consistent with the notion that debt financing is a mechanism to constrain managers to spend corporate resources sensibly and thus enhance corporate performance shareholder value.

Although an impressive body of research from developed and developing countries (see for example, Titman \& Wessels, 1988; Rajan \& Ziangales, 1995; Harris \& Raviv, 1997; Booth, Aivazian, Demirguc-Kunt \& Maksimovic, 2001; Frank \& Goyal, 2009; Vijayakumaran, \& Vijayakumaran, 2011; Du, Guariglia \& Newman, 2013; Guariglia \& Vijayakumaran, 2013) has been devoted to understanding the determinants of capital structure decisions, only a handful of studies examines the effect of these capital structure policy choices on corporate performance (e.g., Dessí, \& Robertson, 2003; Vijayakumaran, 2015). This study fills this gap in the literature by analyzing the performance effects of capital structure decisions for a sample of listed firms in China, the largest emerging economy in the world.

In China, the corporate bonds market lags behind the development of the equity market. Although bonds were first issued in 1986, the corporate bond market has only begun to expand after 2000, when new rules governing issuance were implemented. Recently, local firms, besides the giant State Owned Enterprises (SOEs), are also encouraged to issue corporate bonds and market forces increasingly determine the spread on bonds. Nevertheless, China's bond market is still very small compared to its huge banking sector [See Vijayakumaran \& Vijayakumaran (2017) for a review of Chinese banking system and bond market]. Therefore, Chinese banks play a crucial role in the financing of firms. However, Chinese government's ownership of both banks and firms hampers bank lending to serve as an effective governance mechanism in mitigating agency costs for the firms due to soft budget constraints faced by them (Tian \& Estrin, 2007; Firth, Fung, \& Rui, 2008). Yet, recent research suggests that following the liberalization of China's financial system and the improvement in the corporate governance of the banking sector, banks now use more and more commercial judgment and prudence in their lending decisions (Ayyagari, Demirguc-Kunt \& Maksimovic, 2008; Firth, Lin, Liu, \& Wong, 2009) and loan officers in 
banks and other financial institutions are held responsible for their poor lending decisions (Allen, Qian, Zhang \& Zhao, 2012). Consequently, Chinese banks play an important role in monitoring corporate activities and improving the efficiency of corporations. In light of these developments, recent research using data on Chinese listed firms suggests that bank financing no longer facilitates unwise investment and the overconsumption of perquisites in SOEs. In other words, it now act as a disciplining device that constrains managers' misconduct and thus help improve investment efficiency in both state controlled and privately controlled firms (see e.g., Chan, Dang, \& Yan, 2012; Lin \& Bo, 2012; Tsai, Chen, Lin \& Hung, 2014; R.Vijayakumaran, 2014; S.Vijayakumaran, 2016). As such, in this study, we provide additional evidence on the effectiveness of banking system reform initiated by the Chinese government, and the governance role of debt financing by examining whether debt financing helps to improve corporate performance by reducing agency costs of equity for Chinese listed firms. This is the main aim of this paper.

Using a panel of 4181 firm year observations of Chinese listed industrial firms over the period 2003 to 2010, we find that debt financing is positively related to corporate performance of the firms, implying that debt financing in fact works as a governance mechanism for Chinese listed firms and thus helps to enhance their performance.

The reminder of the paper is organized as follows. Section 2 reviews relevant literature and develops hypothesis. Research design including sample, model and estimation methods and variables are discussed in Section 3. Section 4 discusses empirical results. Section 5 concludes with summary and suggestions for potential avenues for future research.

\section{Review of the Literature and Hypothesis}

\subsection{Agency Problem, Capital Structure and Corporate Performance}

The existence of principal-agent relationship in modern corporations where shareholders (principals) employ an agent to perform a service by delegating decision-making authority to the agent may lead to agency problems. Agency theory suggests that the separation of ownership and control in corporations and information asymmetries lead to conflicts of interest between managers and outside shareholders as well as those between controlling and minority shareholders (Berle \& Means, 1932; Jensen \& Meckling, 1976; Shleifer \& Vishny, 1986; Morck, Wolfenzon, \& Yeung, 2005). For example, managers may exert insufficient work effort, over-consume perquisites, invest in unrelated business to build empires, or otherwise fail to maximize firm value while controlling shareholders may expropriate corporate resources through related party transactions at the expenses of minority shareholders. Thus, agency conflicts and the resultant agency costs represent important issues in corporate governance and capital structure literature.

Agency theory also suggests that the choice of capital structure can act as a disciplinary mechanism in mitigating these agency conflicts and thus contributes to an improvement on firm performance. Greater debt financing may provide mangers with the incentives to reduce agency costs through the threat of liquidation, which causes personal losses to managers of salaries, reputation, etc. (e.g., Grossman \& Hart, 1982; Williams, 1987). Jensen (1986) argues 


\section{Mll Macrothink}

International Journal of Accounting and Financial Reporting

ISSN 2162-3082

2017, Vol. 7, No. 2

that debt commits managers to disgorge free cash flow, thus it reduces the amount available to managers to over-invest.

\subsection{Prior Evidence}

Only a limited number of empirical studies investigate the performance effect of leverage and provide mixed evidence. For example, using a sample of US firms for the years 1976, 1986, and 1988a, McConnell and Servaes (1995) report that leverage is positively related to Tobin's $\mathrm{Q}$ in a low-growth firm whereas leverage is negatively related to Tobin's $\mathrm{Q}$ in a high-growth firm. However, their study does not control for potential endogeneity problem.

Focusing on a sample of 557 UK firms over the period 1967 to 1989, Dessi and Robertson (2003) find that debt is positively associated with firm performance when they do not control for endogeneity of debt. Yet, they show that the relationship disappear when they control for the endogeneity in the static and dynamic modeling framework. By contrast, Berger and Bonaccorsi di Patti (2006) use a sample of 7548 US firms in the banking industry over the period 1990 to 1995 and report a positive relationship between leverage and firm performance, controlling for potential endogeneity arising from reverse causality. More recently, Margaritis and Psillaki (2010) use a sample of French manufacturing firms over the period 2002 to 2005 and report that leverage has a non-linear (inverted U-shaped) relationship with performance.

Researches focusing on emerging market also examine the relationship between leverage and corporate performance. Examples of these are Krishnan and Moyer (1997) who, focusing on large firms from four emerging economies in Asia, show that leverage has negative but insignificant impact on performance. Using 167 Jordanian companies over a fifteen year period, Zeitun and Tian (2007) report that a significant negative association between capital structure and firm performance measured by both the accounting and market measures. Rao, Al-Yahyaee, \& Syed (2007), using a sample of Omani firms, show a negative relationship between the level of debt and financial performance. Focusing on a panel of listed manufacturing firms in the Colombo Stock Exchange (CSE) over the period 2008-2013, and using Generalized Method of Moments (GMM) methodology to control for unobserved heterogeneity, endogeneity of capital structure decisions, Vijayakumaran (2015) finds that leverage is non-linearly (U-shaped) related to firm performance, suggesting that as levels of leverage increases, debt capital is not efficiently utilized in the firm to increase performance; instead, it may be used by controlling shareholders to expropriate corporate resources, which negatively affect firm performance. Yet, after a threshold level is reached, further increase in debt capital help to improve performance by constraining entrenchment behavior of controlling shareholders through the threat of liquidation and the close monitoring by the lenders.

\subsection{Hypothesis}

As discussed above, empirical studies provide mixed evidence on the performance effects of leverage. In the context of China, bank loans are the major source of debt capital for firms. Given that with the liberalization of China's banking system and the improvement in the 
corporate governance of the banking sector, Chinese banks play an important role in monitoring corporate activities and improving the efficiency of corporations (Firth et al., 2009; Allen et al., 2012; Chan et al., 2012; Lin \& Bo, 2012; Tsai et al., 2014), we would expect debt financing to work as a governance mechanism to constrain managers' opportunistic behaviour, reduce agency costs of equity and thus positively affect corporate performance of Chinese listed firms. We therefore hypothesize that:

\section{H1: There is a positive relationship between levels of leverage and firm performance.}

\section{Research Design}

\subsection{Sample and Dataset}

The sample is composed of all the publicly listed industrial firms traded on the Shanghai and Shenzhen stock exchanges. The data used in this study are obtained from two Chinese databases namely, the China Stock Market Accounting Database (CSMAR) and Sino-fin for the period of 1999-2010. To reduce the influence of potential outliers, we exclude observations in the one percent tails of each of the regression variables. We also lag all our independent variables once (except volatility and firm age). After computing variables as defined below and screening, we end up with a panel of 4181 firm-year observations on 853 companies over the period 2003-2010 for our empirical analysis. The panel has an unbalanced structure.

\subsection{Model and Estimation Methodology}

To examine the extent to which capital stature decisions affects corporate performance, we estimate following panel data regression model that links corporate performance with capital structure decisions and firm characteristics:

$$
\begin{aligned}
& R O A_{i t}\left(R_{O} O E_{i t}\right)=\beta_{0}+\beta_{1} T L E V_{i t-1}+\beta_{2} F S I Z E_{i t-1}+\beta_{3} F S I Z E_{i t-1}^{2}+\beta_{4} T A N G_{i t-1}+\beta_{5} S G R O W_{i t-1}+ \\
& \beta_{6} V O L T_{i t}+\beta_{7} A G E_{i t}+v_{i}+v_{t}+\varepsilon_{i t}
\end{aligned}
$$

where $i$ indexes firms, $t$ years. Table 1 provides definitions and expected signs for all variables used in this paper. The error term in Equation (1) is made up of three components: $v_{i}$ is a firm-specific effect; $v_{t}$, is a time-specific effect, which we control for by including time dummies capturing business cycle effects and $\varepsilon_{i t}$ is an idiosyncratic component.

Most of the prior studies from developing countries that examines the relation between corporate performance and capital structure decisions use pooled OLS (Ordinary Least Square) regressions. However, the pooled OLS regression does not take into account the potential endogeneity of debt arising from the unobserved firm heterogeneity, for example, managerial ability (Zwiebel, 1996), which affect both the firm's choice of capital structure and its expected performance. Thus, OLS estimator is more likely to provide biased estimates of the coefficient on debt. Therefore, to address the potential endogeneity issue, we first use fixed effects regression which enable us to control for the possibility that endogeneity arises from omitted unobserved factors. Second, we regress the contemporaneous performance measures on the one-period lag values of leverage and other explanatory variables. The lag allows for 
the effect of change in the sample firms' capital structure decisions to show up in future firm performance.

\subsection{Variables}

\subsubsection{Dependent Variables}

In this study, we use two alternative proxies to measure corporate performance, namely return on assets $(R O A)$ and return on equity $(R O E)$. While $R O A$ is defined as net income (net profit) divided by total assets, $R O E$ defined as net income divided by total equity.

\subsubsection{Capital Structure Variable}

The independent variable is total leverage (denoted by TLEV), which is used to capture the effect of capital structure decisions on corporate performance. Following Dessi and Robertson (2003) and Margaritis and Psillaki (2010), leverage is defined as the ratio of total debt to total assets. As discussed earlier, for Chinese listed firms, we would expect a positive relationship between leverage (TLEV) and performance.

\subsubsection{Control Variables}

In line with prior literature (e.g., Dessi \& Robertson, 2003; Margaritis \& Psillaki, 2010), our regression model (equations 1) also includes several additional variables to control for a set of firm-specific observable characteristics that are likely to be correlated with firms' performance. These include firm size (FSIZE), squared term of firm size $\left(F S I Z E^{2}\right)$, tangibility (TANG), sales growth $(S G R O W)$, volatility $(V O L T)$ and firm age $(A G E)$. This exercise would enable us to single out the impact of capital structure decisions on firm performance from other observable firm characteristics.

Firm size (FSIZE) is measured by the natural logarithm of real sales at the firm level. A positive relationship between firm size and corporate performance is often considered as a stylized fact, as larger firms are expected to use better technology, be more diversified and better managed. Larger firms may also enjoy economies of scale in monitoring top management and have a higher capacity for taking risks (Himmelberg, Hubbard, \& Palia, 1999; Greenaway, Guariglia \& Yu, 2014; Dixon, Guariglia, \& Vijayakumaran, 2015). However, larger firms are likely to suffer from hierarchical managerial inefficiencies and thus incur larger agency costs (Williamson, 1967). Thus, following Himmelberg et al. (1999) and Margaritis and Psillaki, (2010), we allow for nonlinearities in the effect of firm size on performance by including the square of the natural log of sales in the performance equations.

Tangibility (represented by TANG), is measured by the ratio of tangible fixed assets to total assets. Diverse relationships can be observed between firms' performance and tangibility depending on the degree of efficient utilization of tangible assets by the firm. If a firm utilizes its tangible assets efficiently, then we would expect a positive relationship between tangibility and performance, otherwise the relationship would be negative.

Growth opportunities are proxied by annual growth of real sales which is denoted by SGROW. Since growth opportunities represent a firm's growth prospects and investment opportunities, 


\section{MlMacrothink}

International Journal of Accounting and Financial Reporting

ISSN 2162-3082

there should be a positive relationship between the growth opportunities and performance. Previous empirical studies also report a positive effect of growth opportunities on firm performance (see e.g., Claessens, Djankov, Fan \& Lang, 2002; King \& Santor, 2008). Vijayakumaaran (2015) finds an insignificant relationship between growth opportunities and performance for Sri Lankan listed manufacturing firms.

We also include a measure of volatility of firms' earnings (denoted by VOLT), defined as the standard deviation of the first differences of earnings before taxes and depreciation over the four years preceding the sample period, and divided by average total assets for that period. Firms with greater earnings volatility are more likely to have lower profitability. Finally, we include firm age $(A G E)$ measured by natural logarithm of the number of years since the establishment of the firm. Firm age is expected to have a negative association with firm profitability, given that older firms are likely to be former SOEs and suffer from grater agency problems, which negatively affects firm performance.

Table 1. Variable definitions and expected signs

\begin{tabular}{|c|c|c|c|}
\hline Variables & Acronyms & Measures & $\begin{array}{l}\text { Expected } \\
\text { sign }\end{array}$ \\
\hline \multicolumn{4}{|c|}{ Dependent Variable } \\
\hline \multirow{2}{*}{ Performance } & $R O A$ & Return on assets : Net income/ total assets & \\
\hline & $R O E$ & Return on equity :Net income/ total equity & \\
\hline \multicolumn{4}{|c|}{ Independent variables } \\
\hline Leverage & $T L E V$ & Total leverage/ total assets & $+(\mathrm{H} 1)$ \\
\hline \multicolumn{4}{|c|}{ Control variables } \\
\hline \multirow[t]{2}{*}{ Size } & $F S I Z E$ & Natural logarithm of total sales & + \\
\hline & $(F S I Z E)^{2}$ & Square of FSIZE & - \\
\hline Tangibility & $T A N G$ & Fixed assets/ Total assets & + \\
\hline Sales growth & SGROW & $\begin{array}{l}\text { Difference between sales of end of year } t \text { and } \\
\text { end of year } t-1 \text { divided by sales end of year } \\
t-1\end{array}$ & + \\
\hline Volatility & $V O L T$ & $\begin{array}{l}\text { Standard deviation of the first differences of } \\
\text { earnings before taxes and depreciation over } \\
\text { the four years preceding the sample period, } \\
\text { divided by average total assets for that } \\
\text { period. }\end{array}$ & - \\
\hline Firm age & $A G E$ & $\begin{array}{l}\text { Natural logarithm of the number of years } \\
\text { since the establishment of the firm }\end{array}$ & - \\
\hline Year dummies & $v_{t}$ & Year dummies for the years 2004 to 2010 & \\
\hline
\end{tabular}




\section{MlMacrothink}

\section{Empirical Results}

\subsection{Descriptive Statistics}

Table 2 presents descriptive statistics for the variables used in the analysis for our pooled sample. The pooled mean (median) return on assets (ROA) and return on equity (ROE) are $2.5 \%(2.5 \%)$ and $4.1 \%(5.5 \%)$, respectively. The average total debt to asset ratio is $51.3 \%$ (the median is $52.3 \%$ ), suggesting that more than $50 \%$ of the industrial firms' assets are financed by debt capital. With respect to the control variables included in our model, average size of the sample firms measured by real sales is about $1.85(0.947)$ billion RMB. The average tangible assets of the firms proxied by the ratio of fixed assets to total assets is given by $48.7 \%(48.8 \%)$. The average (median) sales growth, measured as changes in real sales, is $17.6 \%(14.8 \%)$. The mean (median) of the volatility is $4.5 \%(3.0 \%)$. Finally, the average (median) firm age is 11.7 years (11 years).

These summary statistics indicate that the sample used in this study is comparable to those used in prior research in the Context of China.

Table 2. Summary statistics

\begin{tabular}{lcccccc}
\hline Variable & Obs & Mean & Median & Std. Dev. & Min & Max \\
\hline Return on assets $($ ROA $)$ & 4181 & 0.025 & 0.025 & 0.057 & -0.334 & 0.205 \\
Return on equity $($ ROE $)$ & 4181 & 0.041 & 0.055 & 0.143 & -0.957 & 0.339 \\
Leverage (TLEV) & 4181 & 0.513 & 0.523 & 0.163 & 0.069 & 0.915 \\
Firm size (FSIZE) (billion RMB) & 4181 & 1.854 & 0.947 & 2.826 & 0.088 & 25.659 \\
Tangibility (TANG) & 4181 & 0.487 & 0.488 & 0.150 & 0.106 & 0.822 \\
Sales growth (SGROW) & 4181 & 0.176 & 0.148 & 0.309 & -0.557 & 2.262 \\
Volatility (VOLT) & 4181 & 0.045 & 0.030 & 0.043 & 0.004 & 0.294 \\
Firm age $($ AGE) & 4181 & 11.713 & 11.000 & 3.602 & 5.000 & 25.000 \\
\hline
\end{tabular}

Notes: This table reports summary statistics of the variables used in our study. All variables are defined in Table 1. It should be noted that although firm size is measured as the natural logarithm of real sales in the regression analysis, the figures reported in Table 2-the descriptive statistics are not in logarithms but as actual values.

\subsection{Correlation Analysis}

Table 3 reports the Pearson correlation coefficients between variables. Total leverage (TLEV) shows a negative and statistically significant correlation with firms' performance measured by both $R O A$ and ROE. This result is inconsistent with our hypothesis (H1). However, confounding factors may be behind such opposite association; as we discussed in the methodology, we address this issue in the multivariate analysis that follows in the next section.

Turning to control variables, firm size (FSIZE) has a significant positive correlation with both 
measures of performance. The ratio of tangible fixed assets to total assets (tang) has a negative and significant association with both $R O A$ and $R O E$. As expected, sales growth $(S G R O W)$ is positively and significantly related to $R O A$ and $R O E$, while both measures of firm performance show a significant negative association with volatility (VOLT). Finally, while firm age $(A G E)$ exhibits a negative and significant correlation with $R O A$ and surprisingly, it is not significantly related to $R O E$. Furthermore, Table 3 suggests that given that the observed correlation coefficients between independent variables are relatively low, multicollinearity should not be a serious problem in our study.

Table 3. Correlation matrix

\begin{tabular}{|c|c|c|c|c|c|c|c|c|}
\hline & $R O A_{i t}$ & $R O E_{i t}$ & $T L E V_{i t-1}$ & $F S I Z E_{i t-1}$ & $T A N G_{i t-1}$ & $S G R O W_{i t-1}$ & $V O L T_{i t}$ & $A G E_{i t}$ \\
\hline$R O A_{i t}$ & 1 & & & & & & & \\
\hline$R O E_{i t}$ & $0.90 *$ & 1 & & & & & & \\
\hline$T L E V_{i t-1}$ & $-0.30 *$ & $-0.17 *$ & 1 & & & & & \\
\hline$F S I Z E_{i t-1}$ & $0.19 *$ & $0.21 *$ & $0.22 *$ & 1 & & & & \\
\hline$T A N G_{i t-1}$ & $-0.06^{*}$ & $-0.04 *$ & $0.14 *$ & $0.14^{*}$ & 1 & & & \\
\hline$S G R O W_{i t-I}$ & $0.31 *$ & $0.31 *$ & $0.06 *$ & $0.13 *$ & $0.06^{*}$ & 1 & & \\
\hline$V O L T_{i t}$ & $-0.22 *$ & $-0.21 *$ & $0.07 *$ & $-0.19^{*}$ & $-0.06^{*}$ & $-0.08^{*}$ & 1 & \\
\hline$A G E_{i t}$ & $-0.04 *$ & -0.03 & $0.12 *$ & $0.06^{*}$ & $-0.04 *$ & $-0.08^{*}$ & $0.13 *$ & 1 \\
\hline
\end{tabular}

Notes: This table reports Pearson correlation coefficients. * denotes significance at the 5\% level or more. See Table 1 for definitions of all variables.

\subsection{Multivariate Analysis}

Table 4 presents estimation results of our regression model (1) using fixed effects regression. In Column 1 of Table 4, we first estimate a model in which the ROA is regressed on leverage, and a set of control variables including firm size, tangibility, sales growth, volatility, firm age and a set of year dummies.

Firstly, the coefficient on leverage is positive and statistically significant at the $1 \%$ level. In line with hypothesis $\mathrm{H} 1$, this finding suggests that there is strong evidence of a positive relationship between leverage and corporate performance. This result is in marked contrast to the empirical findings of prior studies (Tian \& Estrin, 2007; Firth et al., 2008) that shows that Chinese government's ownership of both banks and firms weakens monitoring incentives of banks and thus, bank lending does not to serve as an effective governance mechanism in mitigating agency costs for firms. 


\section{Ml Macrothink}

International Journal of Accounting and Financial Reporting ISSN 2162-3082

Table 4. Relationship between corporate performance, capital structure decisions and firm characteristics

\begin{tabular}{|c|c|c|}
\hline & (1) & (2) \\
\hline & $R O A$ & $R O E$ \\
\hline$T L E V_{i t-1}$ & $0.074^{* * *}$ & $0.164^{* * * *}$ \\
\hline & $(4.49)$ & $(3.81)$ \\
\hline$F S I Z E_{i t-1}$ & $-0.097^{* * *}$ & $-0.048^{* *}$ \\
\hline & $(-2.97)$ & $(-2.06)$ \\
\hline$F S I Z E^{2}{ }_{i t-1}$ & $0.004^{* *}$ & $0.005^{*}$ \\
\hline & $(2.16)$ & $(1.79)$ \\
\hline$T A N G_{i t-1}$ & $-0.025^{* * * *}$ & $-0.021^{* * * *}$ \\
\hline & $(-2.62)$ & $(-3.21)$ \\
\hline$S G R O W_{i t-1}$ & $0.016^{* * * *}$ & $0.003^{* * * *}$ \\
\hline & $(4.89)$ & $(5.45)$ \\
\hline$V O L T_{i t}$ & $-0.05^{* * *}$ & $-0.098^{* * * *}$ \\
\hline & $(-3.88)$ & $(-2.84)$ \\
\hline$A G E_{i t}$ & -0.013 & -0.378 \\
\hline & $(-0.70)$ & $(-0.40)$ \\
\hline Constant & $2.403^{* * *}$ & $4.591^{* *}$ \\
\hline & $(3.49)$ & $(2.13)$ \\
\hline Year fixed effects & Yes & Yes \\
\hline Firm fixed effects & Yes & Yes \\
\hline Observations & 4181 & 4181 \\
\hline adj. $R^{2}$ & 0.098 & 0.093 \\
\hline F value & 23.15 & 19.47 \\
\hline$p$-value & 0.000 & 0.000 \\
\hline
\end{tabular}

Asterisks denote statistical significance at the $1 \%(* * *), 5 \%(* *)$, or $10 \%(*)$ level, respectively. Reported in parentheses are t-values based on clustered standard errors that are robust to unknown heteroscedasticity and within-firm serial correlation. See the Table 1 for definitions of the variables.

Yet, our result is consistent with the most recent research which argues and provide evidence that with the liberalization of China's financial system and the improvement in the corporate governance of the banking sector, debt financing (as we discussed earlier, bank loans are the major source of debt capital for Chinese firms) acts as a governance mechanism that constrains managers' self-interested behaviour and thus help improve investment efficiency in both state controlled and privately controlled firms (see e.g., Chan, Dang, \& Yan, 2012; Lin \& Bo, 2012; Tsai, Chen, Lin \& Hung, 2014; Vijayakumaran, 2014). Similarly, our result also implies that when leverage becomes relatively high, monitoring incentives of lenders increases which in turn make managers to avoid their misconducts and align their interests with that of shareholders and thus improve firm's performance. This finding is consistent 


\section{Mll Macrothink}

International Journal of Accounting and Financial Reporting

ISSN 2162-3082

2017, Vol. 7, No. 2

with Saker and Saker (2006), R.Vijayakumaran (2014) and S.Vijayakumaran (2016) who provide empirical evidence consistent with the idea that with the institutional developments over the period, debt financing has emerged as an important governance mechanism to mitigate agency costs of equity for firms in India and China, respectively.

Now we turn to the control variables. The estimated coefficient of firm size (FSIZE) is negative and significant at the $1 \%$ level while the coefficient of its square $\left(F S I Z E^{2}\right)$ is positive and statistically significant at the 5\% \% level, suggesting that large firms enjoy economies of scale, and face less asymmetric information problem and thus are able to obtain external debt capital at lower cost of capital, resulting in higher profitability. The coefficient associated with tangibility is negative and significant at the $1 \%$ level. This result suggests that Chinese industrial firms do not efficiently utilize tangible fixed assets. We observe that sales growth $(S G R O W)$ is positively and significantly associated with $R O A$ at the $1 \%$ level, implying that firms with high growth potential are more profitable. As we expected, the coefficient of volatility (VOLT) negative and highly significant, meaning that firms that experience high volatility in their operating profits are likely to be less profitable. Finally, the coefficient of firm age is not significant at conventional significant levels, suggesting that firm age does not affect firm's profitability.

\subsection{Robustness Tests}

We also replicate our regression model using alternative performance and leverage measure to assess whether our results are sensitive to the specific performance measures we select. First, we estimate our regression model with return on equity $(R O E)$ as a performance measure instead of ROA. As can be seen in Column 2 of Table 4, the result shows that once again, leverage still display a positive coefficient, and it is precisely determined. This confirms that debt financing is positively related to corporate performance predicted by our hypothesis H1. As for the control variables, they show a similar pattern as in column 1 of Table 4. As further robustness tests, we estimate regression model 1 with debt to equity ratio and bank debt to total assets ratio as two alternative measures of debt financing instead of debt to total assets, in unreported results, we observe that results are qualitatively similar to those reported in Table 4.

\section{Conclusions}

The agency models of capital structure choices suggests that debt financing is one of the important mechanisms to mitigate agency problems and thus to improve corporate performance. This study examines the relationship between capital structure decisions and performance of Chinese listed industrial firms, using fixed effects method. The study uses 4181 firm year observations over the period 2003-2010.

The study documents a strong positive relationship between levels of leverage and firm performance. This implies that as levels of leverage increases, debt capital positively affects firm performance, suggesting that for Chinese listed firms debt capital serve as a mechanism to mitigate agency costs of equity capital by constraining managers' self-interested behaviour. 


\section{Macrothink}

International Journal of Accounting and Financial Reporting ISSN 2162-3082

Our study has important policy implications in that it suggests that lenders such as banks should closely monitor borrower firms' behaviour and ensure that their loans are not inefficiently used or are not used by managers to reap private benefits. Bank regulators may also put more restriction on the use of debt capital by firms. Furthermore, by providing important evidence on the efficacy of China's financial system reform, in general and one of the important governance mechanisms, namely debt financing, in particular, our study also provides new insights into the future directions of corporate governance reforms in China. Finally, in this study, we rely on quantitative and secondary data to test our hypothesis; but future research, using qualitative research methods such as questionnaire based survey or interview, could be conducted in order to complement our study.

\section{Acknowledgement}

Dr. Ratnam Vijayakumaran thankfully acknowledges financial support from the University of Jaffna for this research.

\section{References}

Abor, J. (2005). The effect of capital structure on profitability: an empirical analysis of listed firms in Ghana. The Journal of Risk Finance, 6(5), 438-445.

Allen, F, Qian, J, Zhang, C., \& Zhao, M. (2012). China's financial system, opportunities and challenges. National Bureau of Economic Research Working paper, no. 17828. Cambridge, MA: National Bureau of Economic Research.

Ayyagari, M., Demirguc-Kunt, A., \& Maksimovic, V. (2008). How well do institutional theories explain firms' perceptions of property rights?. Review of Financial Studies, 21, 1833-1871. https://doi.org/10.1093/rfs/hhl032

Barnea, A., Haugen, R. A., \& Senbet, L. W. (1981). Market imperfections, agency problems, and capital structure: a review. Financial Management, 7-22.

Berger, A. N., \& Di Patti, E. B. (2006). Capital structure and firm performance: A new approach to testing agency theory and an application to the banking industry. Journal of Banking \& Finance, 30(4), 1065-1102.

Berle, A. A., \& Means, G. G. C. (1991). The modern corporation and private property. Transaction publishers.

Booth, L., Aivazian, V., Demirguc-Kunt, A., \& Maksimovic, V. (2001). Capital structures in developing countries. The Journal of Finance, 56(1), 87-130.

Chan, K. S., Dang, G. T., \& Yan, I, K, M. (2012). Financial reform and financing constraints: Some evidence from listed Chinese firms. China Economic Review, 23, 482-497.

Claessens, S., Djankov, S., Fan, J. P., \& Lang, L. H. (2002). Disentangling the incentive and entrenchment effects of large shareholdings. The Journal of Finance, 57(6), 2741-2771.

Dessí, R., \& Robertson, D. (2003). Debt, Incentives and Performance: Evidence from UK Panel Data. The Economic Journal, 113(490), 903-919. 


\section{MInstitute Macrothink $_{\text {Int }}$}

International Journal of Accounting and Financial Reporting ISSN 2162-3082

Diamond, D. W. (1991). Debt maturity structure and liquidity risk. The Quarterly Journal of Economics, 709-737.

Dixon, R., Guariglia, A., \& Vijayakumaran, R. (2015). Managerial ownership, corporate governance and firms' exporting decisions: evidence from Chinese listed companies. The European Journal of Finance, 1-39. http://doi/abs/10.1080/1351847X.2015.1025990

Du, J., Guariglia, A., \& Newman, A. (2015). Do Social Capital Building Strategies Influence the Financing Behavior of Chinese Private Small and Medium Sized Enterprises?. Entrepreneurship Theory and Practice, 39(3), 601-631.

Firth, M., Fung, P. \& Rui, O. M. (2008). Ownership, governance mechanisms, and agency costs in China's listed firms. Journal of Asset Management, 9(2), 90-101.

Firth, M., Lin, C., Liu, P., \& Wong, S. M. (2009). Inside the black box: Bank credit allocation in China's private sector. Journal of Banking \& Finance, 33(6), 1144-1155. https://doi.org/10.1016/j.jbankfin.2008.12.008

Frank, M. Z., \& Goyal, V. K. (2009). Capital structure decisions: which factors are reliably important?. Financial Management, 38(1), 1-37.

Greenaway, D., Guariglia, A., \& Yu, Z. (2014). The more the better? Foreign ownership and corporate performance in China. The European Journal of Finance, 20(7-9), 681-702.

Grossman, S. J., \& Hart, O. D. (1982). Corporate financial structure and managerial incentives. In The economics of information and uncertainty (pp. 107-140). University of Chicago Press.

Guarigli, A., \& Vijayakumaran, S. (2013). Capital structure decisions and corporate governance: Evidence from the Chinese listed companies. Proceedings of 4th Asia-Pacific Business Research Conference, Singapore. Retrieved from https://wbiworldconpro.com/uploads/singapore-conference-2013/finance/1380694634_310-S unitha.pdf

Harris, M., \& Raviv, A. (1991). The theory of capital structure. The Journal of Finance, 46(1), 297-355.

Himmelberg, C. P., Hubbard, R. G., \& Palia, D. (1999). Understanding the determinants of managerial ownership and the link between ownership and performance. Journal of Financial Economics, 53(3), 353-384.

Jensen, M. C. (1986). Agency costs of free cash flow, corporate finance, and takeovers. The American Economic Review, 76(2), 323-329.

Jensen, M., \& Meckling, W. (1976). Theory of the firm: Managerial behavior, agency costs and ownership structure. Journal of Financial Economics, 3(4), 305-60.

King, M. R., \& Santor, E. (2008). Family values: Ownership structure, performance and capital structure of Canadian firms. Journal of Banking \& Finance, 32(11), 2423-2432. 


\section{Mll Macrothink}

International Journal of Accounting and Financial Reporting

ISSN 2162-3082

2017, Vol. 7, No. 2

Krishnan, V. S., \& Moyer, C. R. (1997). Performance, capital structure and home country: an analysis of Asian corporations. Global Finance Journal, 8, 129-143.

Lin H-C, M., \& Bo H. (2012). State-ownership and financial constraints on investment of Chinese-listed firms: new evidence, The European Journal of Finance, 18(6), 497-513.

Margaritis, D., \& Psillaki, M. (2010). Capital structure, equity ownership and firm performance. Journal of Banking \& Finance, 34(3), 621-632.

McConnell, J. J., \& Servaes, H. (1995). Equity ownership and the two faces of debt. Journal of Financial Economics, 39(1), 131-157.

Modigliani, F., \& Miller, M. H. (1958). The cost of capital, corporation finance and the theory of investment. The American Economic Review, 261-297.

Modigliani, F., \& Miller, M. H. (1963). Corporate income taxes and the cost of capital: a correction. The American Economic Review, 53(3), 433-443.

Morck, R., Wolfenzon, D., \& Yeung, B. (2004). Corporate governance, economic entrenchment and growth (No. w10692). National Bureau of Economic Research.

Myers, S. C. (1977). Determinants of corporate borrowing. Journal of Financial Economics, $5(2), 147-175$.

Myers, S. C., \& Majluf, N. S. (1984). Corporate financing and investment decisions when firms have information that investors do not have. Journal of Financial Economics, 13(2), 187-221.

Rajan, R. G., \& Zingales, L. (1995). What do we know about capital structure? Some evidence from international data. The journal of Finance, 50(5), 1421-1460.

Rao, N.V., Al-Yahyaee, K. H. M., \& Syed, L. A. M. (2007). Capital structure and financial performance: evidence from Oman. Indian Journal of Economics and Business, 1-23.

Sarkar, J., \& Sarkar, S. (2008). Debt and corporate governance in emerging economies Evidence from India1. Economics of Transition, 16(2), 293-334.

Shleifer, A., \& Vishny, R. W. (1986). Large shareholders and corporate control. The Journal of Political Economy, 461-488.

Shleifer, A., \& Vishny, R. W. (1997). A survey of corporate governance. The Journal of Finance, 52(2), 737-783.

Tian, L., \& Estrin, S. (2007). Debt financing, soft budget constraints, and government ownership: evidence from China. Economics of Transition, 15(3), 461-481.

Titman, S., \& Wessels, R. (1988). The determinants of capital structure choice. The Journal of Finance, 43(1), 1-19.

Tsai, Y. J., Chen, Y. P., Lin, C. L., and Hung, J. H., 2014. The effect of banking system reform on investment-cash flow sensitivity: Evidence from China. Journal of Banking \& Finance, 46, 


\section{Macrothink \\ International Journal of Accounting and Financial Reporting \\ ISSN 2162-3082 \\ 2017, Vol. 7, No. 2}

166-176. https://doi.org/10.1111/j.1468-0351.2007.00292.x

Vijayakumaran, R. (2014). Corporate governance and corporate finance: evidence from Chinese listed companies, Unpublished doctoral dissertation. Durham University, Durham. Retrieved from http://etheses.dur.ac.uk/10965/

Vijayakumaran, R. (2015). Capital structure decisions, agency conflict and corporate performance: evidence from Sri Lankan listed manufacturing companies. International Journal of Accounting and Business Finance, 1(1), 1-14. Retrieved from https://papers.ssrn.com/sol3/papers.cfm?abstract_id=2666511

Vijayakumaran, R., \& Vijayakumaran, S. (2011). Determinants of capital structure in Sri Lanka: evidence from panel data. Proceedings of the international conference, of the international conference of Sri Ram Institute of Management Studies, India, 295-305. doi10.13140/RG.2.1.4708.9360

Vijayakumaran, R., \& Vijayakumaran, S. (2017). Institutional reforms and development of corporate governance and banking system in China. Asian Journal of Finance \& Accounting, 9(2). 352-368. https://doi.org/10.5296/ajfa.v9i2.12382

Vijayakumaran, S. (2016). Leverage and debt maturity of Chinese listed firms: determinants and effects on corporate performance, Doctoral dissertation, Durham University. Retrieved from http://etheses.dur.ac.uk/11897/

Williams, J. (1987). Perquisites, risk, and capital structure. The Journal of Finance, 42(1), $29-48$.

Williamson, O. E. (1967). Hierarchical control and optimum firm size. The Journal of Political Economy, 123-138.

Zeitun, R., \& Tian, G. G. (2007). Does ownership affect a firm's performance and default risk in Jordan?. Corporate Governance, 7, 66-82.

Zwiebel, J. (1996). Dynamic capital structure under managerial entrenchment. The American Economic Review, 1197-1215.

\section{Copyright Disclaimer}

Copyright for this article is retained by the author(s), with first publication rights granted to the journal.

This is an open-access article distributed under the terms and conditions of the Creative Commons Attribution license (http://creativecommons.org/licenses/by/4.0/) 